\title{
Distal Ureter
}

National Cancer Institute

\section{Source}

National Cancer Institute. Distal Ureter. NCI Thesaurus. Code C160616.

The segment of the ureter that extends from the lower border of the sacrum to the bladder. 